admirable demonstration of the classic procedures of sociologists, and of the very different manner in which they have developed the concept of evolution and met the questions it poses. It discussed at some length attempts by nineteenth-century and later social scientists to develop evolutionary interpretations of the course of development of language and technology, and less successfully, of religion and law. He then presented his own view of social evolution as a process of development through higher levels of organized complexity of rational ideas, this process being effected by the human capacity for the intercommunication of ideas and skills.

Prof. Lancelot Hogben, by contrast, made his contribution on "Darwinism and Human Society in Retrospect" an exercise in the interpretative view of history he has made his own-which one would like to call philotechnic commensalism: the fortuitous concurrence and subsequent interaction of circumstances, generating complex causal processes which determine the direction and the variations in the rate of cultural development in different sections of the human species. The technological backwardness of the African is thus related to the susceptibility of horses to trypanosomiasis, which "has condemned Africans south of the tropic of Cancer to be their own beasts of burden in territories where malaria, yellow fever, hook-worm infection, schistosomiasis and many other diseases only lately recognized by medical science exact a heavy toll from the vitality of the people". Furthermore, "every change of the human environment through human interference signalizes a new accretion of transmissible experience and a now potential of further change. Because of this, human society is a unique ecological system". Thus, Darwin's work fits logically into its historical position when seen in the context of the stage reached by technological developments available in England by the midnineteenth century; the most significant circumstances being the greater facilities for sea travel offered by steam power, which "both greatly enlarged opportunities for a global survey of living beings and forced the problems of geographical distribution on the attention of naturalists", the accumulation of evidence for evolutionary succession provided by the work of survey and excavation undertaken during the railway-building period, and the major improvements in the microscope. The formulation and reception of Darwin's contribution to evolutionary theory similarly falls into place among the controversies over the criteria which should determine admission to the universities, the Civil Service, commissioned rank in the army and other controllerships, the debate over free competition as a principle of economic welfare and a social ethic, and the re-sharpening of the Abolitionist conflict in the years before the outbreak of the American Civil War.
In turn, the grand theological debates of the next forty years appear now to be locked firmly within their ideological setting; and the fruitless search for a complete genealogy of organic creation, Hogben also suggested, is visible now as the inescapable fate of a biology unprovided with the means of distinguishing adequately between hereditary transmission and genetic variation.

While Hogben's and Waddington's contributions inevitably dominated the conference, as latter-day reflexions by Darwin's scientific successors on the possibilities and limitations of a biological view of human society, other topics bulked larger than this short notice can easily show. Prof. Basil Willey's introductory account of the descent of Darwin's own theories from previous writings, although stretching back to Empedocles, was subject to a good deal of emendation in later discussions; his restriction of the effect of his work to the theological debate was deplored, and his view of Darwin's ultimate religious position as "helping to restore buoyancy to religion by forcing it to abandon some of its more untenable defences" was rejected by both rapporteurs. His paper also, however, bore on Darwin's introduction of the notion of chance into the rational interpretation of universal destiny, ideas far more disruptive than Newtonian mechanics, which had made the retention of the notion of design and of Designer plausible.

Mr. S. A. Barnett, in the last session, returned to the attack on Prof. Waddington's side with a range of suggestions from the study of the behaviour of bees, rats, birds and fish which might throw some light on behaviour in infancy, on motivation or emotion, and on the nature of language and human communication in general. Mr. Tom Burns, in the final paper, regarded these suggestions as limited to a very small field of human conduct, which characteristically selected courses of action from the wide range of possibilities available as normative guides to members of any society.

At the close of this conference, Dr. Bronowski remarked that no title could have lent itself better to so diverse an array of papers on such different subjects. Survivors of conferences on cybernetics may dispute this, but a conference which began with observations on the "history of man's endless probings into the mystery of existence; his thoughts about the nature of reality, about the administration of the universe ..." and ended with a muted discussion on chance as the mechanism of irreversibility, and thus as the instrument of the universal order apprehended by man, has some claim to catholicity. It was also, far more frequently than one expects any conference to be, absorbingly interesting and seminal.

The conference papers will be published in book form.

Tom Burns

\title{
OBITUARIES
}

\section{Dr. L. J. Spencer, C.B.E., F.R.S.}

Leonard James Spencer, who died on April 14 at the advanced age of eighty-eight, was fourth in a line of distinguished keepers of minerals in the British Museum. His predecessors were Story-Maskelyne, appointed the first keeper of the department a century ago, Sir Lazarus Fletcher and G. T. Prior. All three were Fellows of the Royal Society, to which Spencer also was elected in 1925. He was made C.B.E. in 1934, he was given the Murchison Medal of the Geological Society in 1937, and the Roebling Medal of the Mineralogical Society of America in 1941. $\mathrm{He}$ was an honorary member of the Mineralogical Societies of Germany and of America, a senior Fellow of the Geological Society of London, and was president of the Mineralogical Society during 1936-39, and its foreign secretary from 1949 until his death. 
Spencer was born at Worcester on July 7, 1870, the eldest son of James Spencer, for many years headmaster of the Day School Department of Bradford Technical College. According to a note in a local paper on the occasion of his appointment to the British Museum, he was "nurtured on examinations" and "when he had just completed his seventh year he turned his serious attention to geology ... .". From Bradford he went with a Royal Exhibition to the Royal College of Science for Ireland, taking a first in chemistry. Thence with a scholarship he went to Sidney Sussex College, Cambridge. He won the Harkness Scholarship in 1893 and successfully competed for a vacancy in the Department of Mineralogy in the British Museum (Natural History) in the same year. He then went for six months to Munich to study under Paul Groth, using his Harkness Scholarship money for the purpose, and returning to take up his appointment at the Museum on January l, 1894. He married in 1899 Edith Mary, daughter of Islip J. Close, of Mortimer, Berkshire, and leaves a son and two daughters.

Spencer's main achievement in the Department of Mineralogy, apart from his scientific research work, was the establishment of the system of registration, labelling and card-cataloguing the mineral collection. After Prior became keeper in 1909, Spencer did a great part of the registration himself, and one result of his work and of his careful training of those who followed him is that the National Collection of Minerals is now probably the best documented and indexed in the world.

In addition to all his meticulous work on the collection, Spencer's output of original papers was considerable. His publications number well over a hundred and range over a wide field of descriptive mineralogy. He published two books, on minerals and on precious stones, and he translated from the German two large quartos on the same subjects. $\mathrm{He}_{\Theta}$ took up the study of meteorites after Prior's retirement in 1927 and contributed many papers on this subject to the Mineralogical Magazine.

The discovery of the meteorite craters at Henbury in Australia and Philby's discovery immediately afterwards of the crater at 'Wabar' with its slag-like masses of silica-glass black with included millions of tiny spheres of nickel-iron gave great impetus to Spencer's work in this field and led him also to take up the problem of the origin of tektites. He strongly advocated the theory that tektites are the product of the impact of great meteorites on the Earth's surface, a theory that still finds many supporters but remains unproved. It was his interest in these problems that led him at the age of sixty-four to accompany an expedition into the heart of the Libyan Desert to investigate on the spot the masses of yellow silica-glass discovered in 1932 by P. A. Clayton. He hoped to find a meteorite crater there, but returned with the problem of the origin of the glass still a mystery. Spencer retained a very active interest in meteorites right to the end of his life, and his very last publication on meteorites was a communication in Nature of March 8, 1958.

Spencer's work at the British Museum would have filled the working life of some men, but he seemed always to be doing the work of three. In 1901 he took over the editorship of the Mineralogical Magazine from Miers, and he continued to edit it until the end of 1955. Previous to 1901 he had catalogued mineralogical papers for the Royal Society Catalogue for $1883-1900$, and he continued this for the Inter- national Catalogue of Seientific Literature for 190114. In 1920 the Mineralogical Society commenced publication of Mineralogical Abstracts, and Spencer edited it and prepared more than half the abstracts himself. When he retired he had edited twelve volumes covering thirty-six years. A dinner in his honour was given him by his friends in November 1950 on the completion of his fifty years as editor of the magazine, and he lived to see Mineralogical Abstracts appear in a new format as a joint BritishAmerican publication aiming at a still wider international coverage of the science.

\section{W. Campbell Smith}

\section{Dr. Eric Berkeley Higgins}

Dr. Eric Berkelex Higgins, who died suddenly on April 8 at the age of seventy-three, was an inventor of the classical industrialist type, which pioneered industrialism, and is still not quite extinct. He had the peculiar flair for chemical development which seems to combine art and science. After early success with Dr. Ormandy, he invented the use of nickel formate in the hydrogenation of oils, and found his capitalist in Hamburg, where he was busy getting the process started when the First World War broke out.

Higgins was arrested in November 1914, and became one of a large number of Englishmen collected, under very unpleasant conditions, from all over Germany. These finally arrived in the Ruhleben racing stables at Spandau, where most of them stayed for the duration of the War, under the supervision of neutral diplomats. The American ambassador soon condemned one barrack (twenty-four horse boxes with hayloft above) as unfit for human habitation, so this was handed over to the already very active representatives of the arts and sciences among the prisoners. The scientists included established research men in physics, chemistry and biology, one of whom eventually became a Nobel prizeman. Soon a laboratory for teaching and research in all these branches came into existence, and Higgins was one of its most active spirits. He had arrived at the camp with two young men just gazetted out of Woolwich, with a sound mathematical training but no science. Higgins made them both change to science as a career, and one of them received his knighthood for it.

The power which Higgins had to enthuse gifted youth, and gain their warm personal regard, played no small part in his subsequent success, which culminated in Catomance, Ltd., which he worked up from small beginnings on his inventions in waterproofing and mothproofing materials. When he showed the latter some years ago at a chemical exhibition in London, he directed attention to it by providing a fow live moth grubs engaged in chewing wool, with a microphone and loudspeaker which made them audible to visitors. This naturally appealed to the B.B.C. reporter touring the exhibition, and all the world heard the nasty little fellows munching.

Higgins had a mind the energy of which seemed entirely undiminished by several spells of ill-health. $\mathrm{He}$ would be at it hammer and tongs, first at Liverpool making soap, then at Brentford on watersoftening compounds and naphthol $A S$ dyes, then at Welwyn Garden City on the intensive development work which brought prosperity. He enjoyed to the end the affection of the men and women who formed the firm which he created, and all his life-long friends. H. Stafarord Hatrield 